\title{
Visiting Ayurvedic Fermentation for Safe Drugs and Drug Leads
}

\author{
A Sabu and M Haridas* \\ Department of Biotechnology \& Microbiology, Kannur University, India
}

Submission: June 02, 2017; Published: June 06, 2017

*Corresponding author: M Haridas, Inter University Centre for Bioscience and Department of Biotechnology \& Microbiology, Kannur University, Thalassery Campus, Kannur 670661, Kerala, India, Email: mharidasmm@gmail.com

\section{Introduction}

Natural products and compounds are considered significant in developing new drugs and they may remain so for ages. However, they have been put to changes for improving their performances and reducing negative impacts by synthetic means. Could there be a natural way of transforming the natural products and compounds for better results as therapeutic agents instead of going for chemical alterations? Can this be achieved without or with minimum synthetic means? From the history of universal medicine, we may find an encouraging answer: The answer is 'ayurvedic fermentation' or making of ayurvedic wine.

Fermented medicines, ayurvedic wines, are considered generally superior to their respective tinctures for absorption in the gut since it is partly 'digested' [1]. What fermentation would do to the natural compounds present in fermenting media? It may be generalized as: fermentation may convert many of the water-insoluble compounds to water soluble if such compounds are not utilized by the fermenting organisms for their metabolic requirements by breaking down completely or discharging as certain metabolic products. This process has been going on with fermentation, and we have been utilizing such products or by-products without proper understanding of their nature and functions. However, ayurvedic fermentation continued to be in practice for millennia. It is to be noted that all the traditional medical practices and protocols have not been equally popular all the time. It means, if one practice or protocol is getting less popular, that either it may not be delivering good results or a better practice or protocol might have replaced it. This can happen for intra-system practices or protocols too. Fermentative method of herbal drug preparation has been very popular in south Asia for thousands of years without much change. Apparently, no significant change in this method of drug preparation did happen for years, would be probably due to two reasons: a. Nothing was introduced to replace it. b. It was a good system so that it stood up against the test of time.

\section{The changes observed in the ayurvedic medicines due to fermentation}

A few reports exist regarding the changes of phyto constituents present in the poly herbal preparations for fermenting [2-8]. The reports of only Sharanya et al. [2] and Chandra et al. $[1,3,4]$ correlated the structural changes brought about to the chemicals present in the fermenting herbal soup to their changes in medicinal properties. It is found that there is a positive correlation to their medicinal properties due to the changes on fermentation with respect to the compounds of study. The reported changes come under a general category of rendering better water solubility to the less water soluble compounds. In other terms, they are like the metabolic changes due to the function of liver.

\section{The significance of changes due to fermentation}

The biotransformation of medicinally important compounds would deliver them better in water solubility and bioavailability implicating as superior therapeutic leads in specified instances. It has been observed in certain cases, that the fermentative changes are comparable to metabolic changes, as functions of human liver. If such fermentative changes enhance the medicinal function of such compounds, then such property-enhanced medicinal compounds will be available for longer period for the system onto which the medicines are applied. They may be qualified to be vaguely called as 'pro-drugs' which are better than the parent drug compound. And, some of such changes are considered similar to the consequence of roles played by probiotic micro organisms that are normal residents of our gut. It is quite surprising that the two thousand years or more old 
ayurvedic classic text speculated part-digestion by medicinal fermentation.

\section{The prospects of drug designing research on leads from ayurvedic wines}

There are many ayurvedic wines containing spices and other herbs which may form the sources for many drugs or basic materials for semi synthetic drugs. There are ayurvedic wines which contain grapes. There is no report that, resveratrol or such important poly phenol derivatives that are commonly found in red wine and considered significant in ameliorating heart diseases are present in ayurvedic wines. Their presence must be looked into. If the medicinal repertoire of ayurvedic wines is carefully examined, more precious drugs or drug leads and scaffolds for semi synthetic drugs for diseases like cancer would be found. It may be considered logically and hopefully that their possibility to be developed to a drug may be high because of better pharmacological activity, favourable pharmacokinetic and pharmacodynamic behaviours or less toxicity. This is the obvious advantage of fermenting poly herbal preparations into medicinal wines: to enhance their value. Valiathan \& Thatte [9] have emphasized the need of experimenting with traditional medicine for better products. The drugs developed/designed based on the above premises may have only less chance of failing in getting approval from authority.

\section{Acknowledgement}

$\mathrm{MH}$ gratefully acknowledges the Kerala State Council for Science, Technology and Environment for an emeritus scientist's position.

\section{References}

1. Chandra DN, Preethidan D S, Sabu A, Haridas M (2015) Traditional fermentation of Ayurvedic medicine yields higher pro-inflammatory enzyme inhibition compared to wine-model product. FLS(2): 160-164.

2. Sharanya CS, Shabeer Ali H, Sabu A, Haridas M (2017) Fermentation of polyherbal preparations as in Ayurveda: a novel protocol for drug-lead discovery (MS under review).

3. Chandra DN, Prashanth GK, Singh N, Kumar S, Jithesh O, et al. (2011) Identification of a novel and potent inhibitor of phospholipase A2 in a medicinal plant: Crystal structure at $1.93 \AA$ and Surface Plasmon Resonance analysis of phospholipase A2 complexed with berberine. Biochim. Biophys Acta 1814(5): 657-663.

4. Chandra DN, Joseph A, Prasanth GK, Sabu A, Sadasivan C, et al. (2012) Inverted binding due to a minor structural change in berberine enhances its Phospholipase A2 inhibitory effect. Int J Biol Macromol 50 (3): 578-585.

5. Okutsu K, Yoshimitsu M, Kakiuchi N (2007) Differences in volatile compounds between tincture and ayurvedic herbal liquor asava made from ginger or jujube. J Tradit Med 24(6): 93-99.

6. Chen Y, Inaba M, Abe N, Hirota A (2003) Antimutagenic activity of 8-Hydroxyisoflavones and 6-Hydroxydiadzein from soybean miso. Biosci. Biotechnol. Biochem 67(4): 903-906.

7. Ress NB, Hailey JR, Maronpot RR, Bucher JR, Travlos GS (2003) Toxicology and Carcinogenesis studies of microencapsulated citral in rats and mice. Toxicol Sci 71(2): 198-206.

8. Horsten SFAJ, van den Berg AJJ, Kroes BH, Labadie RP (1990) Hydrolysis of gallotannins by two Aspergillus niger strains isolated from a model preparation of Nimba arishta. Planta Med 56: 586-587.

9. Valiathan MS, Thatte U (2010) Ayurveda: Time to experiment. Int J Ayurveda Res 1(1): 3

\section{Your next submission with Juniper Publishers} will reach you the below assets

- Quality Editorial service

- Swift Peer Review

- Reprints availability

- E-prints Service

- Manuscript Podcast for convenient understanding

- Global attainment for your research

- Manuscript accessibility in different formats

( Pdf, E-pub, Full Text, Audio)

- Unceasing customer service

Track the below URL for one-step submission https://juniperpublishers.com/online-submission.php 